\title{
Pengembangan Kurikulum Berbasis Nusantara dan Internasional di PAUD Fastrack Funschool Yogyakarta
}

\author{
Siti Umayah ${ }^{1}$, Suyadi ${ }^{2}$ \\ ${ }^{1,2}$ UIN Sunan Kalijaga Yogyakarta
}

\begin{abstract}
DOI : https://doi.org/10.15642/jeced.v2i1.505
Abstract

Early childhood education is a children's educational institution that has the aim of learning to develop children's intelligence by using a variety of innovative learning programs. The purpose of this study was to find out how the development of an archipelago-based and international curriculum program in learning was implemented at Fastrack Funschool Yogyakarta. From the results of research conducted by researchers show that in the learning process applying the archipelago curriculum program uses learning with multiple intelligence methods, in which developing linguistic intelligence, logical mathematical intelligence, spatial visual intelligence, musical intelligence, kinesthetic intelligence, iterpersonal intelligence, intrapersonal intelligence, natural intelligence, and, spiritual intelligence whereas in the international curriculum the learning model of seven habits of successful people includes being a proactive person, setting clear targets, working according to priorities, always thinking of profitable ways, trying to understand and then understanding, creating synergies, and always taking time to improve The ability of these multitude of intelligence and habituation is considered to be very effective in learning in early childhood education institutions at Fastrack Funschool Yogyakarta.
\end{abstract}

\begin{tabular}{l} 
Abstrak \\
\hline PAUD merupakan sebuah lembaga pendidikan anak yang mempunyai \\
tujuan pembelajaran mengembangkan kecerdasan anak dengan \\
menggunakan berbagai macam program pembelajaran yang inovatif. Tujuan \\
penelitian ini adalah untuk mengetahui bagaimana pengembangan program \\
kurikulum berbasis nusantara dan internasional dalam pembelajaran yang di \\
terapkan di Fastrack Funschool Yogyakarta. Dari hasil penelitian yang \\
dilakukan peneliti menunjukkan bahwa dalam proses pembelajaran \\
menerapkan program kurikulum nusantara menggunakan pembelajaran \\
dengan metode multiple intelegences yang diantaranya dapat \\
mengembangkan kecerdasan linguistik, kecerdasan matematika logis, \\
kecerdasan visual spasial, kecerdasan musikal, kecerdasan kinestetik, \\
kecerdasan interpersonal, kecerdasan intrapersonal, kecerdasan natural, dan, \\
kecerdasan spiritual sedangkan dalam kurikulum internasional model \\
pembelajaran tujuh pembiasaan orang sukses diantaranya menjadi pribadi \\
yang proaktif, menetapkan target yang jelas, mengerjakan sesuai dengan \\
prioritas, selalu memikirkan cara yang menguntungkan, berusaha memahani \\
lalu dimengerti, wujudkan sinergi, dan selalu meluangkan waktu untuk \\
meningkatkan kemampuan. Multiple intelegences dan pembiasaan tersebut \\
dinilai sangat efektif dalam pembelajaran di instansi pendidikan anak usia \\
dini di Fastrack Funschool Yogyakarta.
\end{tabular}

\section{Article Info}

Article history:

Received: 29022020

Accepted: 15032020

Published online: 15062020

\section{Keywords:}

Nusantara, International

Multiple Intelegences

7 Habbits.

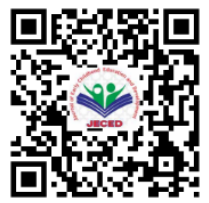

\begin{tabular}{l}
\hline Informasi Artikel \\
\hline Riwayat Artikel \\
Revisi terakhir: 29022020 \\
Diterima: 15032020 \\
Publikasi online: 15062020 \\
\hline
\end{tabular}

\section{Kata kunci:}

Nusantara,Internasional Multiple Intelegences

7 Habbits. 


\section{PENDAHULUAN}

Pendidikan anak usia dini merupakan pendidikan utama bagi anak sebelum memasuki jenjang pendidikan selanjutnya, dalam sebuah lembaga pendidikan anak usia dini harus mempersiapkan tentang kebutuhun apa yang dibutuhkan dalam proses pembelajaran, selain fasilitas perlengkapan seputar permainan, sebuah lembaga pendidikan anak usia dini harus merancang sebuah program pembelajaran yang di dalamnya memuat semua aspek perkembangan anak dintarannya pengetahuan berbahasa asing atau bahasa inggris yang menjadi salah satu bahasa internasional, tetapi juga dalam proses pembelajarannya juga tidak melupakan kultur atau ciri khas kebudayaan bangsa Indonesia.

Berdasarkan inovasi dan kreaktivitas setiap lembaga pendidikan anak usia dini berlomba-lomba menyajikan program pembelajaran yang unggulan sebagai ciri khas atau sebagai nilai tambah tersendiri sebagaimana sekolah itu di kenal oleh masyarakat, bagaimana sekolah itu menjadi salah satu sekolah unggulan, program kurikulum tidak hanya sebuah pembelajaran saja tetapi juga harus memenuhi semua kebutuhan anak, baik dalam dunia nusantara maupun internasional. Sehingga dalam penyususunan program pembelajaran dan kurikulum harus mencangkup semua aspek perkembangan anak bagaimana cara mengembangkan semua aspek perkembangan anak yang dibutuhkan.

Inovasi merupakan sebuah perubahan atau memodifikasi agar menjadi lebih baik, sedangkan pembelajaran merupakan serangkaian kegiatan yang didalamnya desainnya melibatkan proses belajar antara siswa atau anak didik, program pembelajaran yang telah dirancang, dikembangkan dan dikelola secara kreatif, dinamis, multi agar terciptanya sebuah situasi pembelajaran yang kondusif sesuai dengan kebutuhan yang dibutuhkan anak dalam mengembangkan aspek perkembangan anak usia dini.

Sedangkan program pembelajaran merupakan sebuah rumusan-rumusan tentang apa yang hendak dilakukan guru dan peserta didik dalam sebuah lembaga pendidikan untuk mencapai tujuan dimana program pembelajaran di susun sedemikian rupa di sesuaikan dengan perkembangan anak dan kebutuhan anak dalam proses pertumbuhan dan perkembangannya.

Anak usia dini, merupakan individu yang berusia nol sampai enam Tahun. Sebuah individu yang sedang dalam tahap proses bertumbuh dan berkembang yang dinilai mempunyai keunikan tersendiri dalam proses pertumbuhan dan perkembangan.(Mansur, 2005, p. 87-88) Menurut Biechler dan Snowman berpendapat bahwa pada tahap ini anak yang berumur tiga sampai enam tahun sedang dalam program persiapan sebelum memasuki pendidikan dasar. Di Indonesia sendiri memiliki lembaga untuk menitipkan anak dengan jenjang usia antara tiga sampai lima tahun, dalam kelompok bermain anak berusia dua sampai dengan empat tahun sedangkan dalam program taman kanak-kanak usia anak empat sampai enam tahun. Pendidikan anak dilaksanakan pada anak usia 0-8 tahun dalam tahapan bayi, balita, pra sekolah, sekolah dasar.(Patmono Soemiart , 2013, p. 19)

Dengan demikian dapat ditarik sebuah kesimpulan bahwa pada tahap pra sekolah sekelompok individu yang berusia 0-6 tahun yang sedang dalam proses tumbuh kembang baik secara fisik maupun psikis yang berjalan sangat cepat sehingga pada tahap ini sering diartikan sebagai tahap yang di anggap tahap paling jaya. Pada tahap ini merupakan sebuah tahapan yang sangat berpengaruh apabila di kembangkan dengan baik, sesuai dengan tahap perkembangan anak dan kebutuhan anak. 
Menurut Charlles Program Pembelajaran merupakan perencanaan kegiatan dalam proses pembelajaran untuk mencapai tujuan pembelajaran yang telah ditentukan, . Sedangkan menurut Mc Dafid J.L \& Hawtrhoran, L.R.L mendefinisikan program sebagai hubungan makna yang dirancang dan ditetapkan berdasarkan Purposive. Sebuah program yang dapat dipahami dari sekelompok aktivitas yang mempunyai tujuan untuk mencapai sebuah target atau tujuan tertentu.(Susi Susanti, Murwitaningsi, 2016, p. 45) Farida Yusuf Tayibnabis mengartikan bahwa program merupakan segala sesuatu yang dilakukan seseorang dengan harapan akan mendapatkan hasil atau pengaruh. Dalam pengertian terdapat empat unsur pokok dalam sebuah program diataranya (1) kegiatan yang direncanakan atau disusun dengan seksama atau disusun dengan pikiran yang cerdas dan penuh dengan inovasi (2) kegiatan yang berlangsung secara berkelanjutan dengan kata lain keterkaitan dari satu kegiatan ke kegiatan yang lain (3) kegiatan tersebut berlangsung dalam organisasi atau lembaga formal maupun non formal (4) dalam proses kegiatan tersebut dalam pelaksanaanya atau implementasinya melibatkan banyak orang, kegiatan yang dilakukan bukan dilakukan perorangan tetapi harus dilakukan oleh sekelompok orang.(Widoyoko, (2009), p. 227)

Program Nusantara adalah program pembelajran yang disusun untuk mencapai sebuah tujuan pembelajaran berbasis keindonesiaan yang berisi ragam budaya Indonesia baik dalam segi adat kebiasaan dalam berpakaian maupun dalam bahasa daerah yang ada di Indonesia. Yang disusun oleh sebuah lembaga, dan dalam proses kegiatannya di lakukan secara berkesinambungan dan berkelanjutan.

Program internasional merupakan program yang disusun untuk mencapai sebuah tujuan pembelajaran yaitu untuk mengenalkan budaya internasional, untuk mengenalkan kepada anak tentang kebudayaan-kebudayaan internasional diantaranya dengan mengenalkan bahasa inernasional kepada anak yaitu bahasa inggris.

Model Pembelajaran, Menurut Kemp program pembelajaran merupakan sebuah kegiatan yang harus dilaksanakan untuk mencapai sebuah tujuan yang hendak dicapai. Sama dengan pendapat Kemp, Dick dan Carey menyebutkan juga dalam program sebuah pembelajaran itu merupakan seperangkat materi yang di kemas dan di laksanakan dalam mencapai sebuah tujuan yang hendak di capai, atau yang menjadi sebuah target. Upaya dalam melaksanakan program yang telah ditentukan untuk mencapai hasil yang maksimal sesui dengan apa yang di targetkan maka di butuhkan sebuah metode atau cara yang dinilai tepat dalam mencapai sebuah target yang telah ditentukan.

Bentuk strategi dalam pendidikan yang telah ditentukan dalam proses penerapannya dapat di modifikasi desesuaikan dengan kegiatan pembelajaran berdasarkan pola pembelajaran yang telah ditetapkan.(Suyadi, \& Maulidya Ulfah, 2017, p. 19) Karena dalam sebuah metode pembelajaran atau model pembelajaran yang digunakan harus sesuai dengan tahap perkembangan anak atau juga bisa juga sesuai dengan usia anak, karena jika model pembelajaran yang digunakan tidak sesuai yang perlu di waspadai adalah tahap perkembangan anak tidak sesuai dengan apa yang diharapkan.

Dalam sebuah pembelajaran perilaku guru adalah mengajar dan prilaku siswa adalah belajar, perilaku tersebut berkaitan dengan strategi dan peralatan belajar, petunjuk dalam sebuah pembelajaran dapat berupa wawasan, karakter, budaya, agama tingkah laku dan keahlian. Berdasarkan hasil dari penelitian para tokoh terhadap aktivitas antara pendidik dan peserta didik dengan keterkaiatan bahan ajar yang merupakan sebuah tehnik pembelajaran. Dalam sebuah penelitian yang bertemakan 
bentuk pembelajaran yang dilakukan oleh ahli Amerika tahun 1950, yang bernama Marc Belth penelitianya dengan berusaha menemukan strategi pembelajaran yang disesusikan dengan kebutuhan dan kinerja otak anak.

Multiple intellegences, Setiap individu memiliki kecerdasan yang beragam dan unik, 'multiple intelegences' telah di kembangkan oleh salah satu ahli peneliti dari Amerika, beliau mendefinikan bahwa setiap individu mempunyai berbagai macam kecerdasan, dengan tingkat kecerdasan yang berbeda antara satu dengan yang lain, disini kecerdasan yang dimaksud berupa suatu keahlian atau keterampilan yang dapat di tingkatkan (Ardimen, 2016, p. 111).

Gardner mendefinisikan bahwa sebuah kecerdasan itu bersifat majemuk atau berbagai macam bentuknya atau sering disebut dengan muttiple intelegences, sedangkan Harvard mengartikan bahwa sebuah kecerdasan itu merupakan bentuk dari sebuah kemampuan dalam memecahkan sebuah masalah yang akan menghasilkan sebuah produk, yang atrinya apabila setiap orang dihapakan dengan sebuah masalah dan dapat menyelesaikannya merupakan bentuk dari sebuah kecerdasan.

Jenis-jenis kecerdasan Multiple intelegences atau sering juga di sebut dengan kecerdasan majemuk diatanrannya berupa (1) Kecerdasan berbahasa, yang berupa kemampuan berkominukasi baik menggukan lisan maupun tertulis. Bentuk dari kecerdasan ini mencangkup kemampuan yang mencangkup ilmu bunyi, ilmu kode dalam bahasa, dan aturan dalam menggunakan bahasa (Pradini Sarah Dzilhijjah, 2016, p. 20). (2) Kecerdasan matematis-logis merupakan kemampuan menggunakan angka dengan baik seseorang dengan kecerdasan matematis logis yang tinggi biasanya memiliki ketertarikan terhadap angka-angka, menikmati ilmu pengetahuan, mudah mengerjakan matematika dalam benaknya, suka memecahkan misteri, senang menghitung, suka membuat perkiraan, menerka jumlah (seperti menerka jumlah uang logam dalam sebuah wadah), dan lain sebagainya (Tadkiroatun musfiroh, 2013, p. 60). (3) Kecerdasan Spasial, kemampuan mempersepsikan dunia spasial-visual secara akurat (misalnya, sebagai pemburu, pramuka, pemandu) dan mentrasformasikan persepsi dunia spasial-visual tersebut (misalnya, decorator interior, arsitek, seniman, atau penemu). Kecerdasan ini meliputi kemampuan membayangkan, mempersentasikan ide secara visual atau spasial, dan mengorientasikan diri secara spasial.(Yatim, Riyanto, 2010, p. 211) (4) Kecerdasan Jasmani, keahlian menggunakan seluruh tubuh untuk mengekspresikan ide dan perasaan (misalnya, sebagai aktor, pemain pantonim, atlet, atau penari) dan keterampilan menggunakan tangan untuk menciptakan atau mengubah sesuatu (misalnya, sebagai perajin, pematung, ahli mekanik, dan dokter bedah). Kecerdasan ini meliputi kemampuan-kemampuan fisik yang spesifik, seperti koordinasi, keseimbangan, keterampilan, kekuatan, kelenturan, dan kecepatan maupun kemampuan menerima rangsangan (proprioveptive) dan hal yang berkaitan dengan sentuhan (tactile \& haptic). (5) Kecerdasan musikal, seorang anak yang memiliki kecerdasan dalam bermusik biasanya senang menyanyi, senang mendengarkan musik, mampu memainkan instrumen musik, mampu membaca not balok/angka, mudah mengingat melodi atau nada, mampu mendengar perbedaan antara instrumen yang berbeda-beda yang dimainkan bersama-sama, suka bersenandung/bernyanyi sambil berpikir atau mengerjakan tugas, mudah menangkap irama dalam suara-suara disekelilingnya, senang membuat suara-suara musikal dengan tubuhnya (bersenandung, bertepuk tangan, menjentikkan jari atau menghentakkan kaki), senang mengarang/menulis lagu-lagu atau ref-nya sendiri dan mudah mengingat fakta-fakta dengan mengarang lagu untuk faktafakta tersebut (Baum Et Al, 2005, p. 203). (6) Kecerdasan Interpersonal merupakan 
kemampuan mempersepsikan dan membedakan suasana hati serta perasaan orang lain. Kecerdasan ini meliputi kepekaan pada eksperesi wajah, suara, gerak isyarat. Kemampuan membedakan berbagai macam tanda dalam berkomunikasi secara efektif, contoh kegiatan tersebut misalnya mempengaruhi anak agar anak tersebut melakukan prilku tertentu (Gardner, Howard, 2003, p. 24). (7) Kemampuan dalam memahami diri sendiri dan melakukan sebuah tindakan berdasarkan apa yang dipahaminya. Kecerdasan ini dapat berupa kemampuan tentang pemahaman diri yang akurat tentang kelebihan dan kekurangan serta kemampuan mendisiplinkan diri dan menghargai diri individu tersebut (Mulyadi Seto, 2012, p. 96). (8) Kecerdasan naturalis, merupan bentuk kecerdasan dalam mengenali dan mengelompokkan gambar tertentu yang berada dilingkungan sekitar, diantaranya hewan tumbuhan dan cuaca, bentuk kegiatan naturalis berupa kemampuan dalam mencintai lingkungam sekitar beserta makhluk hidup yang ada (Pradini Sarah Dzilhijjah, 2016, p. 12), Biasanya yang memiliki kecerdasan naturalis suka memelihara binatang, berkebun atau bercocok tanam dilingkungan sekitar. (9) Kecerdasan eksistensial, merupakan kemampuan menempatkan diri dalam dunia yang luas dan jauh tak terhingga dan menghubungkannya dengan kehidupan selanjutnya (kematian). (10) kecerdasan spiritual, merupakan bentuk dari keyakinan yang timbul didalam diri dengan berdasarkan apa yang dipercayai dan agama sebagai landasanya, dalam kecerdasan ini mencangkup kesadaran hati, keihlasan, kesabaran seperti dalam beragama, mengoptimalkan hubungan dengan tuhan-Nya dengan berlandaskan keyakinan.

Dari pemaparan diatas dapat penulis simpulkan bahwasanya model atau strategi pembelajaran multiple intelegences adalah model pembelajaran yang dapat menstimulus sepuluh bentuk kecerdasan yang dimiliki atau yang terdapat dalam perkembangan anak usia dini, jadi model pembelajaran ini dinilai cocok untuk di kembangkan atau diterapkan dalam sebuah lembaga pendidikan anak usia dini dalam mencapai sebuah program pembelajaran yang menjadi unggulan disekolah yang telah ditentukan.

Metode pembiasaan, berasal dari kata biasa, sehingga pembiasaan diartikan kegiatan yang dilakukan secara berulang-ulang sehingga menjadi sebuah kebiasaan bagi individu, yang berkaitan dengan pendidikan yang menggunakan metode pembiasaan dalam membiasakan berfikir yang kritis, bersikap yang dianggap baik, dan bertindak sesuai dengan aturan yang telah ditetapkan(Armai, Arip, 2002, p. 110), menurut Muhtar Dkk pembiasaan di artikan sebagai kegitan yang dilaksanakan secara teratur dan terus menerus dalam melatih anak agar mempunyai kebiasaan tertentu yang berubungan dengan kepribadian anak seperti meningkatkan kemandirian, hidup disiplin, mengontrol emosi, dan dapat menyesuaikan diri dengan lingkungan sekitar (Muhtar Dkk, 2013, p. 108)dalam pembiasaan sebaiknya harus ada yang mengawasi atau mengontrol tentang kebiasaan-kebiasaan apa saja yang telah anak terapkan, misalnya apakah anak terbiasa bertutur kata yang baik dengan orang yang lebih dewasa atau orang tua dan dalam lingkungan sekolah kegiatan pembiasaan dapat berupa kemandirian, kebersihan tertiban.

Pembiasaan pada dasarnya merupakan sebuah kegiatan yang dilakukan secara berulang-ulang yang berisiskan pengalaman dalam kehidupan sehari-hari. Dengan sebuah pembiasaan yang dilakukan dapat memberikan nilai ples bagi yang melaksanakannya, sebagai contoh ketika seseorang yang dapat menghemat kemudian kegiatan tersebut sudah menjadi kebiasaan yang melekat dan spontan orang tersebut dapat apresiasi dengan kebiasaan yang telah dilaksanakannya, kegiatan pembiasaan dapat digunakan dalam berbagai aktifitas dan pekerjaan lainnya.(Dewi Irpuswanti, \& Mulyasa, 2013., p. 166). 
Menurut Zinal, metode pembiasaan merupakan sebuah cara yang digunakan dalam mengembangkan perkembangan anak yang mencangkup berperilaku, baik dalam agama maupun lingkungan sosial, emosional, dan kemandirian dalam kehidupan sehari-hari sebagai bekal pada kehidupan dimasa yang akan datang (Zainal Akib , 2009, p. 9). Metode pembiasaan yang diplikasikan dalam kehidupan yang dimana dalam sebuah kehidupan sehari-hari kita tidak lepas dari bagaimana berperilaku dilingkungan dengan adanya orang dewasa, bagaimana emosional kita dalam lingkungan masyarakat, hal demikian itu dinilai penting untuk perlu adanya sebuah pembiasaan.

Berdasarkan Departemen Pendidikan dan Kebudayaan, pembiasaan merupakan proses penanaman dalam kegiatan dan pembelajaran anak supaya kegiatan tersebut menjadi sebuah kebiasan (Departemen Pendidikan Nasional., Kamus Besar Bahasa Indonesia. Pustaka, 2015, p. 754). Sedangkan menurut Syaiful Ulil Amri, sebuah metode pembiasaan juga tertuliskan dalam Al-qu'ran, dengan memaparkan penjelasan tentang pembiasaan-pembiasaan hal yang bersifat positif atau kebaikan yang dapat meningkatkan kualitas diri, Sebuah pembiasaan juga tertulis di dalam alquran, dalam sebuah metode pembelajaran yang dilakukan secara bertahap, metode pembiasaan juga tergambar dalam Al-qur'an dalam materi pendidikan melalui pembiasaan yang dilakukan secara bertahap. Dalam hal ini termasuk dalam merubah kebiasaan-kebiasaan yang negatif (Syarif Ulil Amri, 2012, p. 137-138). Ayat-ayat dalam Al-qur'an yang menekankan pentingnya pembiasaan "analis Shalihat" diungkapkan sebanyak 30 kali di terjemahkan dengan kalimat "mereka selalu mengamalkan amal kebaikan" atau "membiasakan beramal shaleh" pentingnya pembiasaan suatu amal kebaikan dalam proses pembinaan dan pendidikan karakter dalam Islam.

Dari beberapa pendapat diatas yang penulis paparkan maka dapat disimpulkan bahwa pembiasaan merupakan sebuah aktivitas yang dijalankan secara berulang-ulang yang menerapkan sebuah kegiatan agar menjadi sebuah kebiasaan. Dalam penerapan pembiasaan kegiatanya yang dilakukan dapat berupa kepribadian yang baik, disiplin diri, kemandirian, dan dapat menaati peraturan yang telah ditetapkan. hal-hal demikian dinilai perlu ditanamkan sejak anak usai dini, karena dalam segala pembelajaran yang berikan kepada anak sejak anak usia dini maka akan anak ingat hingga remaja, dewasa dan tua, dengan demikian sangat penting adanya penerapan sebuah pembiasaan kepada anak.

Adapun bentuk dari kegiatan pembiasaan diantaranya (Zainal Akib, 2009, p. 28) : (1) teratur, aktivitas dilaksanakan setiap hari, bentuk kegiatanya berupa berdoa sebelum beraktifitas (2) spontan, merupakan kegiatan yang dilakukan secara reflek. Misalnya seperti mengucapka kata tolong (3) keteladanan, merupakan bentuk dari kegiatan meniru bentuk kegiatan diantaranya apabila guru menjaga kebersihan maka anak akan mengikutinya (4) terencana, berupa kegiatan yang telah susun dan dijadwalkan akan maksimal dalam prores pelaksanaanya, misalnya seperti RPPH, Prota dan Promes.

Dari pemaparan tentang metode pembiasaan atau habits merupakan sebuah model pembelajaran yang menerapkan sistem yang berkesinambungan berkelanjutan dan berulang-ulang dalam mencapai sebuah program pembelajaran yang ditentukan, model pembelajaran ini juga dinilai sangat afektif dalam mengembangkan perkembangan anak terutama dalam perkembangan nilai-nilai karakter yang kuat pada anak.

Menurut Stephen R Covey dalam kesuksesan seseorang terdapat beberapa faktor pembiasaan yang dapat menunjang seseorang memiliki karakter pemimpin yang diantaranya: menjadi proaktif dalam kegiatan, menentukan target yang tepat dalam kegiatan, dapat melaksanakan kegiatan yang lebih utama, memikirkan sebuah cara yang 
dianggap memberikan keuntungan, dalam melakukan sebuah kegiatan pahami terlebih dahulu apa yang akan dikerjakan, mewujudkan sebuah kepercayaan, dan selalu dapat meluangkan waktu untuk dapat mengembakan kemampuan diri (Evinna Cinda Hendriana, Arnold Jacobus, 2016. p. 25-29).

Tujuh prinsip pembiasaan yang dinilai sangat efektif dalam proses pembelajaran diantaranya (Using Stephen R. Covey's, 2015, p. 16): (1) menjadilah proaktif, anak lebih aktif dalam merespon pembelajaran maupun pertanyaan yang ditanyakan guru (2) menetapkan target yang jelas, dalam proses pembelajaran harus ada tujuan yang jelas yang hendak di capai terutama dalam pembentukan karakter (3) dahulukan yang utama, rencanakan dan kerjakan sesuai dengan prioritas terutama pada target pencapaian (4) memikirkan sebuah cara yang dianggap memberikan keuntungan, dalam melaukan sesuai hal harus di pertimbangkan dahulu apa yang menjadi keuntungan apa bila dikerjakan dan membandingkan kerugian apa yang didapat jika tidak dikerjakan (5) dalam mengerjakan sesuatu dibiasakan untuk memahami terlebih dahulu lalu di mengerti, contohnya membiasakan berfikir terbuka dalam memahami pendapat orang agar dapat menimbulkan kepedulian, saling menghormati, dan dapat memecahkan masalah (6) mewujudkan sinergi, dapat mengembangakan sebuah kerjasama dalam sebuah tim, yang sifatnya positif sehingga dapat mencapai sebuah tujuan dengan cara meningkatkan kontribusi bekerjasama dalam sebuah tim tersebut (7) membiasakan selalu meluangkan waktu untuk dapat mengembakan kemampuan diri sehingga dapat menambah pengetahuan yang dimilikinya dan dapat menciptakan sebuah gaya hidup yang berkelanjutan.

\section{METODE}

Metode pengumpulan data yang digunakan dalam mengumpulkan data menggukan pendekatan kualitatif deskriptif, dimana dalam proses pengumpulan data dilakukan dengan cara mengamati lalu mendeskripsikan suatu keadaan yang ada di lapangan, lalu mengambil dan menjadikan kejadian tersebut sebagai fokus permasalahan yang dijabarkan atau dipaparkan berdasarka fakta dilapangan.

Menurut Craswel, laporan yang ditulis secara kualitatif, tentang pennyelidikan baik individu maupun kelompok yang dianggap bersumber dari kasus kemasyarakatan maupun individual (Cresweel, John W. Penelitian, 2014, p. 24), berdasarkan Bogdan \& Taylor kualitatif merupakan metode penelitian yang memperoleh data yang sifatnya menggambarkan apa adanya gejala yang ada dilapangan (Taylor, Steven, Bogdan, Robert, Devault, Marjorie., Introduction to Qualitative Research Methods: A Guidebook and Resource. John Wiley \& Sons, 2015., p. 8). Sedangkan Moleong memberikan definisi bahwa dalam penelitian kualitatif mengambarkan peristiwa apa yang dialami subjek yang mengeksplor (Moleong, Lexy., , 2010., p. 6).

Dalam penelitian kualitatif sendiri data diperoleh dengan cara observasi atau pengamatan, wawancara atau interview, dokumen analisis. Dan dalam penelitian ini intrumen peneliti adalah peneliti itu sendiri atau key instrumen, intrumen merupakan alat itu sendiri dalam mengumpulkan data dengan tujuan memperoleh data yang sebanyak-banyaknya dan data yang diperoleh dinilai harus akurat. Sedangkan dalam analisis data peneliti menggunakan teknik (1) pengumpulan data yang dilakukan dengan cara observasi, wawancara, atau dokumen analisis (2) reduksi data mengumpulkan data yang dinilai sangat komplek atau sesuai (3) display data (4) penarikan kesimpulan atau verifikasi. 
Berdasarkan pemaparan diatas dapat penulis simpulkan bahwa penelitian kualitatif yang di gunakan dalam penelitian ini bertujuan untuk mengumpulkan data tentang program unggulan pada sekolah Fastrack Funschool, yang dimana peneliti memperoleh data dengan cara observasi, wawancara, dokumen analisis dan penarikan sebuah kesimpulan dari penelitian yang telah di lakukan seputar program unggulan apa saja yang Fastrack Funschool terapkan dalam menstimulus perkembangan anak usia dini.

\section{HASIL PENELITIAN DAN ANALISIS}

Dari hasil penelitian dan analisis yang dilakukan peneliti diperoleh hasil bahwasanya di sebuah lembaga pendidikan anak usia dini Fastrack Funschool, menggunakan program pembelajaran yang didesain dengan dengan begitu kreaktif dan inovatif yang mana dalam program pembelajaran yang diterapkan berpacu pada pengembangan karakter anak, yang dimana karakter anak sangat berpengaruh dalam kehidupan anak, selain itu juga dalam program pembelajaran yang disusun pembelajaran mengacu pada program pembelajaran multiple intelegences yang dimana dalam program pembelajaran tersebut berisikan 10 aspek perkembangan anak yang wajib untuk di kembangkan.

Analisis data penelitan yang dilakukan oleh peneliti diperoleh data bahwasanya berdasarkan program-program pembelajaran dalam meningkatkan dan mengembangkan aspek perkembangan anak usia dini program nusantara dan program internasional dinilai sangat efektif, karena dalam program nusantara banyak hal-hal baru yang diperoleh oleh anak tetapi tidak melupakan nilai keindonesiaan atau nilai kebudayaan, sedangkan dalam program internasional itu sendiri anak diajarkan atau dilatih tentang bagaimana menghadapi kehidupan dimasa depan dengan berbekalkan kepribadian yang berkarakter.

Program pembelajaran nusantara dan program pembelajaran internasional, dengan demikian model pembelajaran multiple intelegences dan model pembelajaran pembiasaan (7 pembiasaan orang sukses) dinilai sangat efektif dalam perkembangan anak dalam membentuk anak bangsa yang berkarakter baik yang mampu bersaing dalam Negeri maupun luar negeri. Berdasarkan hasil dari penelitian yang dilakukan penulis dapat dikatakan dengan adanya kedua program unggulan tersebut, dapat menjadikan sekolah tersebut menjadi salah satu lembaga pendidikan unggulan yang berada di Daerah Istimewa Yogyakarta.

\section{PEMBAHASAN}

Fastrack Funschool merupakan bentuk lembaga pendidikan awal untuk anak yang berada di Daerah Istimewa Yogyakarta, pendiri fastrack funshool sendiri adalah putri sulung dari Gus Dur yang bernama Alisan Wahid yang didirikan pada 26 juni 2010 yang beralamatkan di Jl. Perumnas Tempel Mundusaren Catur Tunggal Depok Sleman Yogyakarta. Lembaga pendidikan ini berdiri dibawah naungan PT Amalan Pribadi. Fastrack Funschool merupakan salah satu pendidikan anak usia dini internasional yang memiliki dua program unggulan, dua program unggulan tersebut diantaranya program internasional dan program internasional, fastrack juga menerapkan program pembelajaran lainnya diantaranya program bermain, program letterland, aikido, iqro, program persiapan sekolah dan program day care.

Dalam lembaga pendidikan anak usia dini Fastrack Funschool terdapat beberapa tata nilai yang diterapkan sebagai dasar pendidikan karakter yang kuat pada anak usia 
dini, yang pertama tentang nilai kebangsaan indonesiaan beberapa nilai yang di ajarkan diantaranya: nilai tentang ketuhanan. Nilai tentang kemanusiaan, nilai tentang persatuan, nilai tentang kebijaksanaan, dan nilai keadilan sosial. Yang kedua tentang living values education: cooperation, happiness, humility, love, peace, respect, responsibility, simplicity, tolerance, unity.

Di Fastrack Funschool sendiri visi dan misi sekolah lebih meningkatkan dan mengembangkan perkembangan karakter pada anak, pendidikan karakter yang diterapkan di Fastrack Funschool didesain supaya anak mandiri,terampil yang mampu menguasai keterampilan kelas mendunia. Teknik penilaian yang digunakan di Fastrack Funschool menggunakan beberapa bentuk diantaranya berbentuk Laporan Harian (Lisan), Laporan Mingguan, Laporan Semesteran, Certificate yang berupa Catatan anekdot, Information Book, Up-date kelas. Di Fastrack Funschool menggunakan kurikulum 13 dan kurikulum tingkat satuan pendidikan yang menyatukan antara multiple intelegences dan pembiasaan dalam mengembangkan program-program pembelajaran.

Berikut program yang menjadi program unggulan di Fastrack Funschool diantaranya Program Nusantara Dan Program Internasional.

\section{Bagan 1. Program unggulan di Fastrack Funschool}
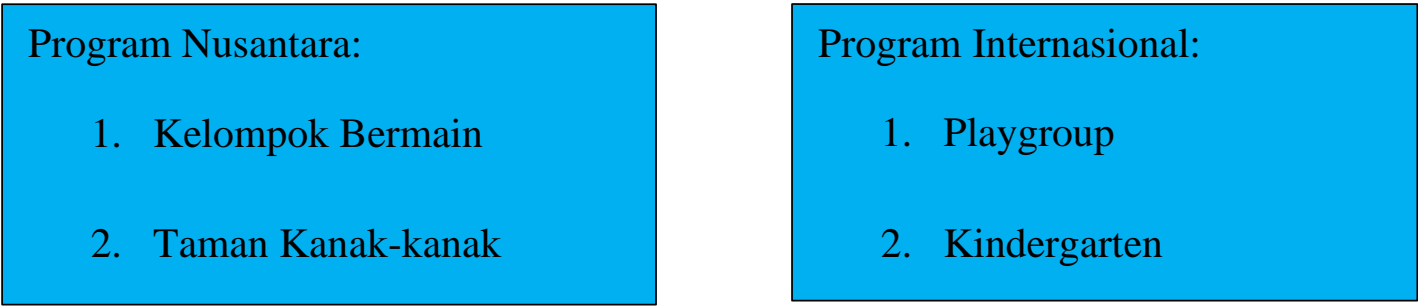

Yang pertama merupakan Program Nusantara, merupakan pragram yang disusun dengan mengacu pada kecerdasan multiple intelegences, supaya semua bentuk kecerdasan yang ada pada anak dapat dikembangkan secara optimal. Dalam program ini telah disusun berdasarkan tingkat usia anak diantaramya:

Kelompok Bermain, dalam kelompok ini jenjang usia anak 2-4 tahun dalam jenjang ini anak memperoleh kesempatan untuk meyalurkan dunianya secara menyenangkan dan bervariasi dengan menjaga ketenangan dan keamanan. Jadwal tersusun secara terstruktur dan luas yang mencangkup semua bentuk kecerdasan yang dimiliki oleh anak, dalam proses pembelajaranya berlangsung selama 2 jam 3 kali dalam satu minggu.

Taman kanak-kanak, dalam kelompok ini jenjang usia anak 4-6 tahun membentuk kelas lanjutan dari kelompok bermain yang dimana pada tahap ini anak memperoleh rangsangan lebih mendalam untuk meningkatkan pengetahuan, pembangunan kepribadian dan keterampilan hidup. Tujuan pokok dari program ini supaya anak mempunyai kematangan dan kesiapan untuk memasuki tingkat pendidikan dasar baik secara kognitif maupun fisik, dalam program ini pembelajaran berlangsung selama 3,5 jam 5 kali dalam satu minggu.

Yang selanjutnya Program internasional merupakan sebuah program yang disusun mengcangkup kecerdasan majemuk yang di kolaborasikan dengan tuju pembiasaan orang sukses dalam membentuk karakter anak. Program tersusun berdasarkan tingkat usia anak. Dengan menerapkan model pembelajaran multiple intelences yang 
mencangkup sembilan aspek kecerdasan yang miliki oleh anak diharakan dapat dikembangkan secara maksimal yang dimana sembilan kecerdasan tersebut diantaranya: kemampuan berbahasa, kecerdasan matematis-logis, Kecerdasan Spasial, Kecerdasan Kinetis-Jasmani, kecerdasan musikal, Kecerdasan Interpersonal, kecerdasan naturalis, kerohanian, dan kecerdasan intrapersonal.

Playgroup dalam kelompok ini jenjang usia anak berusia 2-4 tahun pada jenjang ini anak memperoleh kesempatan menyalurkan dunia lebih kaya dengan menyenangkan dan bervariasi dengan menjaga keamanan dan ketenangan. Jadwal disusun secara terstruktur dan luas yang mencangkup semua bentuk perkembangan anak, proses pembelajaranya berlangsung selama 2 jam 3 kali sehari dalam setiap minggunya.

Kindergarten, dalam kelompok ini jenjang usia anak 4-6 tahun dalam jenjang ini merupakan tahap lanjutan dari playgroop yang dimana dalam tahap ini anak mendapat rangsangan lebih mendalam dalam meningkatkan pengetahuan dalam membangun kepribadian, dan keterampilan hidup. Tujuan inti dari program ini supaya anak mempunyai kematangan dan kesiapan tingkat pendidikan dasar mebaik secara fisik maupun kognitif, dalam program ini pembelajaran berlangsung selama 3,5 jam 5 kali dalam satu minggu.

Dalam kurikulum nusantara pembelajaran yang diterapkan dengan menggunakan multiple intelegences yang di dalamnya memuat sembilan kecerdasan anak, dalam proses kegiatanya bertujuan untuk mengenalkan budaya bangsa Indonesia, dengan contoh kegiatan dalam kurikulum nusantara adalah mengenakan baju adat, membatik, dan tari-tarian. Sedangkan dalam kurikulum internasional pembelajaran yang di terapkan dengan menggunakan 7 pembiasaan orang sukses, dan dalam proses kegiatanya berupa mengenalkan anak dalam baca tulis menggunakan bahasa Inggris.

Pembiasaan yang diterapkan dalam Fastrack Funschool, merupakan sebuah pembiasaan dalam menembangkan karakter anak, yang dimana di dalam pembiasaan tersebut berisikan tentang bagaimana sebuah karakter yang unggul diantaranya: menjadikan anak lebih aktif dalam merespon pembelajaran, melatih anak dalam menentukan sebuah target, melatih anak dalam memecahkan masalah, melatih anak dalam membedakan mana kebutuhan dan mana keinginan, melatih anak dalam memahami kegiatan yang akan dilakukan, melatih anak bekerjasama dalam sebuah tim, dan melatih anak meluangkan waktu untuk mengembangkan keterampilanya.

Strategi dalam pembelajaran yang digunakan atau diterapkan dalam Fastrack Funschool menggunakan kurikulum multiple intelegences dan metode pembiasaan, karena kedua metode tersebut dinilai sangat efektif apabila diterapkan dalam pendidikan anak usia dini. karena metode pembiasaan merupakan kegiatan yang di lakukan secara berulang-ulang untuk menanamkan hal yang sama agar sesuatu itu menjadi suatu kebiasaan, dalam pembiasaan kegiatannya diantarannya keperibadian, emosi, disiplin, budi pekerti, kemandirian, penyesuaian diri hidup bermasyarakat dan lain sebagainya. Sedangkan metode pembelajaran multiple intelegences merupakan starategi pembelajaran dalam mengembangkan kecerdasan anak yang meliputi aspek-kecerdasan, linguistik, matematis spasial, kinestetik, musikal, interpesonal, intrapersonal, naturalis, eksistensial, dan spiritual.

Program pengembangan kurikulum berbasis nusantara dan internasional di PAUD Fastrek Funschool Yogyakarta dinilai sangat efektif, karena dengan metode pembelajaran tersebut dinilai mampu mencetak peserta didik yang berkarakter yang mampu bersaing dalam dunia pendidikan baik dalam tingkat naisional maupun dalam tingkatan internasional, dengan program pembelajaran yang laksanakan sesuai dengan 
apa yang telah dirancang dinilai dapat mengembangkan aspek perkembangan anak secara optimal baik dalam perkembangan moral agama, fisik motorik, kognitif, bahasa, sosial emosional dan seni. Karena dalam multiple intelegences dan seven habit dinilai telah mencangkup enam aspek perkembangan yang terdapat pada anak usia dini harus di stimulus dan dikembangkan.

\section{SIMPULAN DAN SARAN}

Program pembelajaran merupakan sebuah rangkaian pembelajaran yang susun secara terstruktur, dalam pembelajaran berisikan rumusan-rumusan tentang apa yang hendak dilakukan guru dan peserta didik dalam sebuah lembaga pendidikan dalam mencapai sebuah tujuan yang dimana program pembelajaran di susun sedemikian rupa disesuiakan dengan perkembangan anak dan kebutuhan anak dalam proses pertumbuhan dan perkembangannya.

Dari pengumpulan teori dan pengumpulan data di lapangan dapat penulis simpulkan bahwasanya setiap lembaga pendidikan anak usia dini harus memiliki program unggulan yang di susun harus sesuai dengan kebutuhan anak, dalam lembaga pendidikan anak usia dini Fastrack Funschool menggunakan program atau kurikulum nusantara dan inernasional, di dalam proses pembelajaran melatih anak dalam berbahasa asing namun tidak melupakan kultur atau budaya keindonesiaan.

Dalam penerapan program pembelajaran nusantara kurikulum yang di gunakan di kolaborasikan dengan kurikulum multiple intelegences yang dalam proses pembelajarannya mencangkup sembilan kecerdasan anak yang harus di kembangkan pada saat usia dini, sedangkan dalam program internasional kurikulum yang di gunakan di kolaborasikan dengan MI dan tujuh kebiasaan orang sukses, di karenakan pada dasarnya pada lembaga pendidikan Fastrack Funschool yang lebih mengutaman penanaman nilai-nilai karakter pada anak usia dini.

Saran, dalam sebuah lembaga pendidikan anak usia dini harus mampu memodifikasi atau menginovasi program pembelajaran dengan program-program pembelajaran unggulan dengan program pembelajaran yang menarik dan unik dan model pembelajaran yang dapat mampu mengembangkan aspek perkembangan anak usia dini dengan maksimal dengan memperhatikan tahapan perkembangan anak, agar perkembangan dan pertumbuhan anak dapat berkembang secara maksimal dan optimal.

\section{DAFTAR RUJUKAN}

Ardimen, Pengembangan Multiple Intelligence Melalui Pembelajaran Integratif Berbasis Games , Issn : 2460-4917 E-Issn: 2460-5794 Jurnal Edukasi Vol 2, Nomor 2, July 2016.

Armai, Arip, Pengantar Ilmu Dan Metodelogi Pembelajaran Agama Islam., (Jakarta: Ciputat Press, 2002).

Baum Et Al,. Multiple intellegences in the classroom: A Teacher's Toolkit (New York: Teachers College Press, 2005).

Cresweel, John W. Penelitian Kualitatif dan Desain Riset., (Yogyakarta: Pustaka Pelajar, 2014).

Departemen Pendidikan Nasional., Kamus Besar Bahasa Indonesia.,(Jakarta:Balai Pustaka, 2015).

Dewi Irpuswanti, \& Mulyasa, Manajemen Pendidikan Karakter, (Jakarta: Bumi Aksara, 2013). 
Evinna Cinda Hendriana, Arnold Jacobus, Implementasi Pendidikan Karakter Di Sekolah Melalui Keteladanan Dan Pembiasaan., Jurnal Pendidikan Dasar Indonesia Volum 1 Nomor 2 Bulan September 2016.

Gardner, Howard, Kecerdasan Majemuk, Konsep Dalam Praktek Kerja, (Alexander Sindoro, Batam: Interaksa, 2003), n.d.

Mansur, Pendidikan Anak Usia Dini Dalam Islam, (Yogyakarta: Puastaka Pelajar, 2005).

Moleong, Lexy., Metodologi Penelitian Kualitatif (Bandung: PT. Rosdakarya, 2010).

Muhtar Dkk, Orientasi Baru Pendidikan Anak Usia Dini., (Jakarta: Kencana, 2013).

Mulyadi, Seto, Sekolah Anak Juara (Bandung: PT Mizan Pustaka, 2012).

Patmono Soemiarti, Pendidikan Anak Pra Sekolah, (Jakarta: PT Renika cipta, 2013).

Pradini Sarah Dzilhijjah, Implementasi Pembelajaran Berbasis Multiple Intelligences Pada Siswa Kelas Iii Di Sd Jogja Green School, Jurnal Pendidikan Guru Sekolah Dasar Edisi 20 Tahun Ke-5 2016.

Susisusanti, Murwitaningsi, Penialaian Program Siaran Pendidikan Interaktif Televisi bimbingan Mata Pelajaran Ipa, Jurnal Evaluasi Pendidikan Volume 7, Nomor 1, Maret 2016 Doi: Doi.Org 10.21009/Jep.071.08 Terbaik (Jones, 1996:295).

Suyadi, \& Maulidya Ulfah, Konsep Dasar Pendidikan Anak Usia Dini, (Bandung, PT Remaja Rosdakarya, 2017).

Syarif Ulil Amri, Pendidikan Karakter berbasis Al-Qur'an (Jakarta: PT Raja Grasindo Persada, 2012.

Tadkiroatun musfiroh and M Hum, modul 1 hakikat kecerdasan majemuk (Multiple Intelligences) 2013.

Taylor, Steven, Bogdan, Robert, Devault, Marjorie., Introduction to Qualitative Research Methods: A Guidebook and Resource. John Wiley \& Sons, 2015.

Using Stephen R. Covey's The 7 Habits of Highly Effective Peoplein EducationA review of academic literature on the principles taught in., The 7 Habits of Highly Effective People and how these principles apply in the education setting. July 1, 2015.

Widoyoko, E. P. (2009). Evaluasi program pembelajaran (Vol. 91). Yogyakarta: Pustaka Pelajar.

Yatim, Riyanto, Paradigma Baru Pembelajaran. (Kencana, Yogyakarta Prenada Media Group, 2010).

Zainal Akib, Belajar dan Pembelajaran Di Taman Kanak-Kanak., ( Bandung:Yama Widya, 2009).

\section{AUTHOR}

Siti Umayah, dilahirkan di Lampung Barat pada tanggal 3 Agustus 1996. Penulis merupakan mahasiswi Program Magister di Fakultas Ilmu Tarbiyah dan Keguruan Program Studi Pendidikan Islam Anak Usia Dini UIN Sunan Kalijaga Yogyakarta. Penulis saat ini masih menjadi mahasiswa aktif.

Suyadi, lahir di Sleman pada tanggal 3 oktober 1977, merupakan dosen UIN Sunan Kalijaga Program Magister Fakultas Ilmu Tarbiyah dan Keguruan. 